\title{
ELEMENTARY PRE-SERVICE TEACHERS' SELF-EFFICACY IN MATHEMATICS
}

\author{
Darta $^{1}$, Siti Maryam Rohimah ${ }^{2}$, Ahmad $^{3}$ \\ ${ }^{1}$ Program Studi Pendidikan Matematika, Universitas Pasundan \\ 2 Program Studi Pendidikan Guru Sekolah Dasar, Universitas Pasundan \\ ${ }^{3}$ Program Studi Pendidikan Matematika, Universitas Muhammadyah Purwokerto \\ darta_pmat@unpas.ac.id
}

\begin{abstract}
Self-efficacy (SE) is related to someone's belief influencing their success, including success in teaching mathematics for elementary pre-service teachers. This research aimed to analyse: 1) the self-efficacy difference between high-levelled students and moderate-levelled students; 2) the correlation of self-efficacy indicators; 3) correlation of self-efficacy statements, and 4) pattern interpretation of significant correlation tendency between each self-efficacy statement on elementary pre-service teachers. The subjects of this research were the senior students of Primary Education Department in one of private universities in Bandung. The self-efficacy data were obtained from 149 students. The correlation and mean difference test analysis were done with the support of SPSS. The result showed that the self-efficacy of high-levelled students was better than the self-efficacy of medium-levelled students, there was positive significant correlation either for each self-efficacy indicator or self-efficacy statement. From the correlation, there was a meaningful pattern for selfefficacy of elementary pre-service teachers.
\end{abstract}

Key words: self-efficacy, correlation, elementary pre-service teacher. 


\section{Introduction}

Self-efficacy comes from the theory stated by Bandura (2008). According to Bandura (2008), self efficacy is individual belief to their capability in managing and doing some acts to achieve expected results. The expected results can be learning outcomes from some learnings. Learning is a process to make someone study. Each individual has their own way to achieve maximum learning outcomes including believing their own capability in doing assignments or tasks to achieve that outcomes. That individual belief is related to their competence to succeed their assignments and tasks which is called selfefficacy (Dzulfikar, 2013). Similar to Unlu \& Ertekin's opinion (2013) that affective domain influence mathematics learning and teaching such as cognitif domain. One of the most important affective factor is self-efficacy. Therefore, the important component in teaching which leads to someone's learning outcome is self efficacy (SE).

The term of SE describes a behavior of discipline and effort to do wise, precise, and clever move (Hendriana, 2017). Besides, the research of Holzberger, Philipp, \& Kunter (2014) find that self-efficacy and intrinsic needs have commonalities when predicting instructional behavior and the importance of addressing the interaction between personal and environmental characteristics within the learning environment. The next is TschannenMoran, Woolfolk Hoy, \& Hoy, (1998) said that a teacher's sense of self-efficacy has been consistently recognized as an important attribute of effective teaching and has been positively correlated to teacher and student outcomes.

SE is considered important for everyone to owned, including students. Students must have good SE in order to be able to achieve satisfying learning outcomes. The SE which is related to mathematics is called mathematical SE. One of the compulsory subjects learnt by the elementary pre-service teachers is mathematics for elementary schools consisting of the basic concept of mathematics for elementary schools, problem solving of mathematics for elementary schools, learning material and media of mathematics for elemnetary schools, mathematics for lower class, and mathematics for upper class. Mathematical SE is an important component in learning mathematics which needs to be developed.

According to Somakin (2010), the correlations of SE with mathematics learning are those having high selfefficacy who will surely have high selfconfidence and know theirselves really 
well. Students with high self-belief will solve a problem with many ways instead of using only one way. Those with high self-efficacy will obviously continue to learn even when they have graduated. Akay (2010) stated that self-efficacy has been found as a strong predictor to mathematics performance. In other words, the majority of this research stated that there is positive correlation between behavior towards mathematics and success.

There were a lot of research related to $S E$ research which measures correlation between SE and learning outcomes, such as the one belonged to Loo \& Choy (2013) which say that the present study showed that self-efficacy sources were correlated with mathematics achievement scores as well as cumulative GPA of electronicsrelated engineering diplomas. More importantly, mastery experience was found to be the main predictor for academic achievements of mathematics and related engineering modules. The second one belonged to Bates, Latham, \& Kim (2011) which indicate that preservice teachers' mathematics selfefficacy is positively correlated to their personal mathematics teaching efficacy. In addition, their mathematical performance is related to their mathematics self-efficacy and mathematics teaching efficacy. In regard to affecting student outcomes, only those pre-service teachers who are very confident in their ability to teach believe they can have an effect on their students.

However, there are only few research about finding correlation pattern of inter-indicator and each statement of self-efficacy. Therefore, based on the explanation about how important SE is and some research about correlation of SE, these followings will be analyzed in this research: the difference test of SE between the students with high GPA and medium GPA, the analysis results of the correlation of SE inter-indicator, SE interstatement especially with high correlation. The results presented the meaningfulness of correlation tendency pattern either inter-indicator or inter-statement of SE.

\section{Research Method}

Since there were a lot of research related to SE, so there were also a lot of articles discussing about it. However, only few articles which talked about SE on elementary pre-service teachers. Therefore, this research talked about SE on elementary pre-service teachers.

The method of this research was quantitative using Mann-Whitney test and Pearson correlation test, continued with qualitative method using descriptive analysis from quantitative results. The subjects of this research were 149 
students, taken from senior level of Primary Education Department. The SE data were collected using questionnaire adopted from Bandura (2008). There were 20 statements of SE scale. The data of questionnaire results were first changed into interval data using Method of Successive Interval (MSI). Then the next step was looking for the difference of SE between high-levelled and mediumlevelled students, the correlation of interindicator of SE, the correlation of each statement of SE, and finally analyzing the significant pattern of correlation tendency between each SE statement on elementary pre-service teachers. The data were then processed using SPSS in which its process was adjusted to the purpose of the research.

\section{Result and Discussion}

The results of scale analysis of SE (Self-Efficacy) is divided into three categories; difference analysis of SE among students with high and medium GPA, the correlation analysis among SE indicators, and the analysis among SE statements. Furthermore, from the result of those three analyses, there are fixed correlation patterns among the SE statements.

3.1 The Difference of SE among the Students with High and Moderate Level

Determination of students' high and moderate level competence is based on the average of GPA of five subjects related to mathematics, namely: Basic Concept of Mathematics for Elementary Schools, Mathematics Learning for Lower Grade of Elementary Schools, Mathematics Learning for Upper Grade of Elementary Schools, Learning Material and Media of Mathematics, and Mathematical Problem Solving. The results of data processing are shown in Table 1.

Table 1. Statistic Descriptive SE

\begin{tabular}{|c|c|c|c|c|c|}
\hline & & $\mathrm{N}$ & Mean & Std. Deviation & $\begin{array}{l}\text { Std. Error } \\
\text { Mean }\end{array}$ \\
\hline GPA & $\begin{array}{l}\text { High } \\
\text { Moderate }\end{array}$ & $\begin{array}{l}83 \\
66\end{array}$ & $\begin{array}{l}3.7510 \\
3.4406\end{array}$ & $\begin{array}{l}.60242 \\
.56524\end{array}$ & $\begin{array}{l}.06612 \\
.06958\end{array}$ \\
\hline
\end{tabular}

Table 1 shows the mean of the two groups has differences. The average difference will be discussed in Table 2. 
Table 2. Test of Normality

\begin{tabular}{|c|c|c|c|c|c|c|}
\hline & \multicolumn{3}{|c|}{ Kolmogorov-Smirnov $^{\mathrm{a}}$} & \multicolumn{3}{|c|}{ Shapiro-Wilk } \\
\hline & Statistic & Df & Sig. & Statistic & $\mathrm{df}$ & Sig. \\
\hline SE & .060 & 149 & $.200^{*}$ & .989 & 149 & .293 \\
\hline
\end{tabular}

Table 2 revealed that both groups Therefore, it will be continued with Mannof data are not normally distributed. Whitney test as seen in Table 3 .

Table 3. Hypothesis Test Summary

\begin{tabular}{llll}
\hline \multicolumn{1}{c}{ Null Hypothesis } & \multicolumn{1}{c}{ Test } & Sig. & \multicolumn{1}{c}{ Decision } \\
\hline $\begin{array}{l}\text { The distribution of SE is the same across } \\
\text { categories of GPA }\end{array}$ & $\begin{array}{l}\text { Independent Samples Mann- } \\
\text { Whitney U Test }\end{array}$ & .002 & Reject the null hypothesis \\
\hline
\end{tabular}

Asymptotic significances are displayed. The significance level is .01

Table 3 presents the mean scores of SE responses of the respondents. The result of Mann-Whitney test revealed that there was significant diference between the mean scores of the pre-service teacher SE in mathematics.

The statistical results in Table 1 and Table 3 reveal that students' SE scores at upper levels have better SE mean score, because upper level students have higher SE to teach mathematics for elementary schools. The difference of this SE mean score would be confirmed by correlation among SE indicators and correlation among SE statements as seen in Table 4 and Table 5. The differences of better SE at upper level students probably were resulted from the mathematical ability related to mathematic courses. In accordance with the findings of Swackhamer, Koellner, Basile, \& Kimbrough (2009) who demonstrated that in service teachers' efficacy outcome was higher, especially the teachers taking four or more mathematics or science content courses. In fact, by taking some subjects related to mathematics, it also improves SE.

Correlation among Self-Efficacy Indicators

Table 4 revealed the results of correlation statistics using Pearson correlation formula with SPSS. Each indicator showed a positive correlation at the significance level of 0.01 . 
Table 4. Correlation Among Indicators

\begin{tabular}{|c|c|c|c|c|c|}
\hline Indicator & $\mathrm{I}-1$ & $\mathrm{I}-2$ & $\mathrm{I}-3$ & $\mathrm{I}-4$ & $\mathrm{I}-5$ \\
\hline \multicolumn{6}{|l|}{ Students feel optimism (I-1) } \\
\hline $\begin{array}{l}\text { Students feel confident to complete the task or work in elementary school } \\
\text { mathematics well (I-2) }\end{array}$ & $.788 * *$ & & & & \\
\hline Improve the best efforts (I-3) & $.573 * *$ & $.472 * *$ & & & \\
\hline Committed to perform the duties as a student (I-4) & $.729 * *$ & $.724 * *$ & $.580 * *$ & & \\
\hline Responding to diverse situations and conditions in a good and positive way (I-5) & $.567 * *$ & $.522 * *$ & $.677 * *$ & $.701 * *$ & \\
\hline Being based on previous experience as a step to success (I-6) & $628 * *$ & $.636^{* *}$ & $.558 * *$ & $.562 * *$ & $.570^{* *}$ \\
\hline
\end{tabular}

Based on table 4, all indicators have positive correlation statistics. It indicates that all SE indicators have high degree of consistency. It could also be interpreted that all indicators are important, because there is no correlation among them. The correlation is ranged between moderate and high positive. There are 6 pairs of high positive correlation. The highest correlation could be found in pairs I-1 and I-2. It indicates that the indicator of student optimism and belief for completing the mathematics tasks becomes the dominant factor. The correlation between the indicator of student optimism and commitment to accomplish student tasks also becomes the dominant factor.

\subsection{Correlation among Self-} efficacy Statements

Among 20 statements, table 5 only reveals the results of significant and positive correlation statistics using Pearson correlation formula with SPSS. The non-significant correlation is not shown in table 5 because the positive correlations have prominent statements and become the focus of research discussion. There are 11 pairs showing high positive correlations and 17 pairs showing low positive correlations.

Table 5. Correlation among Statement SE

\begin{tabular}{|c|c|c|c|c|c|c|c|}
\hline Statement & S-1 & $\mathrm{S}-2$ & $\mathrm{~S}-3$ & $\mathrm{~S}-4$ & S-5 & S-6 & S-7 \\
\hline \multicolumn{8}{|l|}{$\begin{array}{l}\text { I am able to understand elementary school mathematics well } \\
\text { (S-1) }\end{array}$} \\
\hline I enjoy learning elementary mathematics (S-2) & $.653 * *$ & & & & & & \\
\hline $\begin{array}{l}\text { I set a target in studying elementary mathematics courses ( } \mathrm{S} \text { - } \\
\text { 4) }\end{array}$ & $.558 * *$ & $.551 * *$ & $.672 * *$ & & & & \\
\hline $\begin{array}{l}\text { I'm sure I can teach elementary mathematics well when I } \\
\text { become an elementary school teacher later (S-6) }\end{array}$ & $.371 * *$ & $.388 * *$ & $.517 * *$ & $.482 * *$ & $.630 * *$ & & \\
\hline $\begin{array}{l}\text { I'm sure I can do my elementary school math task well even } \\
\text { though there are many obstacles (S-7) }\end{array}$ & $.358 * *$ & $.307 * *$ & $.504 * *$ & $.490 * *$ & $.615^{* *}$ & $.608 * *$ & \\
\hline $\begin{array}{l}\text { I have understood all the elementary mathematics courses } \\
\text { well (S-8) }\end{array}$ & $.592 * *$ & $.466 * *$ & $.506^{* *}$ & $.530 * *$ & $.619 * *$ & $.507 * *$ & $.558 * *$ \\
\hline
\end{tabular}


Based on the correlation data between S-4 and S-5 having highest positive correlation, it can be interpreted that since the students have a target in basic mathematics course, then they have confidence in doing the mathematics examinations. The second highest correlation statistic is the pair of S-4 and S3. Based on the data, it can be interpreted that since the students have a target, they are sure that they could accomplish the tasks well. The third highest correlation statistic is the pair of S-3 and S-2. It can be interpreted that since the students have a target, they enjoy accomplishing the tasks well.

If the interpretation is compiled from the correlations on table 5 , it can be defined that first, the students arrange the target in their lecturing (S-4). Since they have already had the target, they enjoy the course of mathematics for elementary schools (S-2). Since they enjoy it, they are able to understand materials of the course (S-1). When the students understood materials of the course, they can do the tasks well (S-3). When the students could do the tasks well, they could answer the mathematics tests $(\mathrm{S}-5)$.

The students are able to pass test of mathematics for elementary schools consistently although there are many obstacles in completing the task, they can solve it (S-7). Since they can accomplish mathematics tasks despite of many obstacles, they are able to understand all the course materials (S-8). Finally, the students have confidence to teach mathematics someday (S-6).

This series of correlations are in accordance with the results of research conducted by Corkett, Hatt, \& Benevides (2011) that the study examined the relationship between teacher self-efficacy, student self-efficacy, and student ability. Teacher perceptions of the student selfefficacy were positive correlated with student abilities. Finally, the teacher selfefficacy was positive correlated with their perception of the student self-efficacy.

Therefore, it can be recommended that in order to teach mathematics for elementary schools, the students must have targets, have a fun learning environment, improve their self-belief that they can understand the subject. It is expected that finally they have strong confidence to teach mathematics for elementary school. This is in accordance with Tschannen-Moran \& Johnson's (2011) research results stating that a teacher sense of self-efficacy has been consistently recognized as an important 
attribute of effective teaching and has been positively correlated to teacher and student outcomes.

\section{Conclusion}

Self-efficacy is an important factor that contributes to the success of mathematics learning of elementary preservice teachers. Higher categorized students have a better SE than those with moderate category. There is a high positive correlation between SE indicators and SE statements. The pattern that can be obtained from correlation test results among SE statements for the students are to set the target and the commitment on the mathematics lecture, to enjoy the learning process, and to do the tasks and examinations well. Therefore, the students comprehend all the mathematics materials and have strong sense of efficacy to teach mathematics for elementary school in the future, when they teach in elementary schools.

\section{References}

Akay, H. \& Boz, N. The Effect of Problem Posing Oriented Analyses-II Course on the Attitudes toward Mathematics and Mathematics Self-Efficacy of Elementary
Prospective Mathematics Teachers. Australian Journal of Teacher Education. Vol. 35, Issu 1, Artikel 6 (2010).

Bandura, A. Self-Efficacy. (Tersedia: http://www.des.emory.edu/mfp/Ba nEncy.html, diakses 9 Oktober 2012). (2008)

Bates, A. B., Latham, N. \& Kim, J. Linking Preservice Teachers' Mathematics Self-Efficacy and Mathematics Teaching Efficacy to Their Mathematical Performance. School Science and Mathematics111,325-333 (2011).

Corkett, J., Hatt, B. \& Benevides, T. Student and teacher self-efficacy and the connection to reading and writing. Canadian Journal of Education34,65-98 (2011).

D. Holzberger, A. Philipp, M. Kunter, Predicting teachers' instructional behaviors: The interplay between self-efficacy and intrinsic needs. Contemporary Educational Psychology. 39, 100-111 (2014).

Dzulfikar, A. Studi Literatur: Pembelajaran Kooperatif dalam Mengatasi Kecemasan Matematika dan Mengembangkan Self-Efficacy 
Siswa. Dalam Prosiding Seminar Nasional Matematika, 9 November 2013 di Jurusan Pendidikan Matematika FMIPA UNY (2013). ISBN: 978-979-16353-9-4.

Hendriana, H. \& Sumarmo, Hard Skill dan Soft Skill Matematik Siswa, PT Refika Aditama, Bandung (2017).

L. E. Swackhamer, K. Koellner, C. Basile, D. Kimbrough, Increasing the selfefficacy of inservice teachers through content knowledge. Teacher Education Quarterly, 63-78 (2009).

Loo, C. W. \& Choy, J. L. F. Sources of SelfEfficacy Influencing Academic Performance of Engineering Students. American Journal of Educational Research1,86-92 (2013).

Somakin, Peningkatan Kemampuan Berpikir Kritis dan Self-efficacy Siswa Sekolah Menengah Pertama dengan Penggunaan Pendekatan Matematika Realistik, Tidak diterbitkan, Disertasi Prodi Pendidikan Matematika SPS UPI (2010).

Tschannen-Moran, M. \& Johnson, D. Exploring literacy teachers' self- efficacy beliefs: Potential sources at play. Teaching and Teacher Education27,751-761 (2011).

Ünlü, M. \& Ertekin, E. The Relationship between Mathematics Teaching Self-efficacy and Mathematics Self-efficacy. Procedia - Social and Behavioral Sciences106,3041-3045 (2013) 
